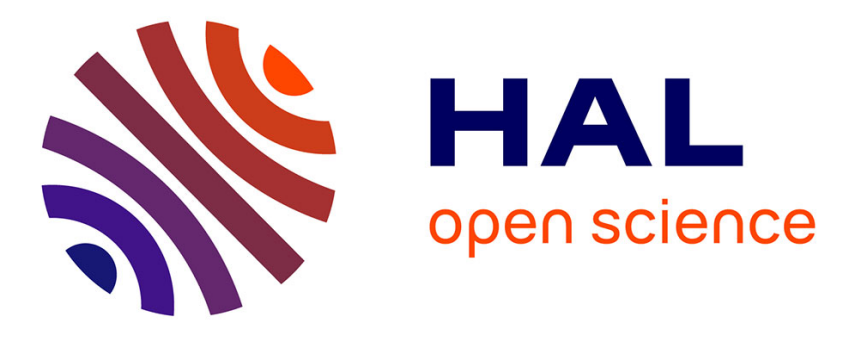

\title{
Can We Speak of Pottery and Amphora 'Import Substitution' in Inland Regions of Roman Africa?
}

Michel Bonifay

\section{To cite this version:}

Michel Bonifay. Can We Speak of Pottery and Amphora 'Import Substitution' in Inland Regions of Roman Africa?. David J. Mattingly; Victoria Leitch; Chloë N. Duckworth; Aurélie Cuénod; Martin Sterry; Franca Cole. Trade in the Ancient Sahara and Beyond, Cambridge University Press, pp.341368, 2017, Trans-Saharan Archaeology. halshs-01956351

\section{HAL Id: halshs-01956351 https://shs.hal.science/halshs-01956351}

Submitted on 30 Jan 2022

HAL is a multi-disciplinary open access archive for the deposit and dissemination of scientific research documents, whether they are published or not. The documents may come from teaching and research institutions in France or abroad, or from public or private research centers.
L'archive ouverte pluridisciplinaire HAL, est destinée au dépôt et à la diffusion de documents scientifiques de niveau recherche, publiés ou non, émanant des établissements d'enseignement et de recherche français ou étrangers, des laboratoires publics ou privés. 
Trade in the Ancient Sahara and Beyond
Edited by
D. J. MATTINGLY
V. LEITCH
C. N. DUCKWORTH
A. CUÉNOD
M. STERRY
F. COLE
Trans-Saharan Archaeology
Series editor:
D. J. Mattingly

幽

? 
Lead isotope analysis of curse tablets from Roman Carthage, Tunisia. Journal of Archaeological Science 39: 970-83.

Skeates, R. 1993. Mediterranean coral: its use and exchange in and around the Alpine region during the later neolithic and copper age. Oxford Journal of Archaeology 12: 281-92.

Spaer, M. 1992. The Islamic glass bracelets of Palestine: preliminary findings. Journal of Glass Studies 34: 44-62.

Stern, E.M. 1998. Interaction between glassworkers and ceramicists. In P. McCray (ed.), Ceramics and Civilisation Volume VIII. The Prehistory and History of Glassmaking Technology, Ohio: The American Ceramic Society, 183-204.

Sterry, M. and Mattingly, D.J. 2011. DMP XIII: Reconnaissance survey of archaeological sites in the Murzuq area. Libyan Studies 42: 103-16.

Sterry, M. and Mattingly, D.J. 2013. Desert Migrations Project XVII: Further AMS dates for historic settlements from Fazzan, South-West Libya. Libyan Studies 44: 127-40.

Sterry, M. Mattingly, D.J. and Higham, T. 2012. Desert Migrations Project XVI: Radiocarbon dates from the Murzuq region, Southern Libya. Libyan Studies 43: 137-47.

Stos-Gale, Z., Gale, N.H., Houghton, J. and Speakman, R. 1995. Lead isotope data from the Isotrace Laboratory, Oxford: Archaeometry data base 1, ores from the Western Mediterranean. Archaeometry 37.2: 407-15.

Tagart, C. 1982. A glass fish beaker from Fezzan. Libyan Studies 13: 81-4.

Tekki, A. 2009. Recherches sur la métallurgie punique, notamment les objets en alliages à base de cuivre à Carthage. Unpublished $\mathrm{PhD}$ thesis, Université Aix-Marseille.

Vanacker, C. 1979. Tegdaoust II. Recherches sur Aoudaghost. Fouille d'un Quartier Artisinal. Nouakchott: Institut Mauritanien de la Recherche Scientifique.

Vanacker, C. 1983. Cuivre et métallurgie du cuivre à Tegdaoust (Mauritanie Orientale). Découvertes et problèmes. In Echard 1983, 89-107.

Van der Sleen, W.G.N. 1956. Trade-wind beads. Man: 27-9.

Willett, F. and Sayre, E.V. 2006. Lead isotopes in West African copper alloys. Journal of African Archaeology 4.1: 55-90.

Wilson, A.I. 2012. Saharan trade: Short-, medium- and long-distance trade networks in the Roman period. Azania: Archaeological Research in Africa 47.4: 409-49.

Zerboni, A. and Vignola, P. 2013. Garamantian green stone beads from Fewet. In Mori 2013, 157-67.
12 Can We Speak of Pottery and Amphora 'Import Substitution' in Inland Regions of Roman Africa?

MICHEL BONIFAY

\section{Introduction}

The focus of this chapter is an examination of patterns of consumption and production in inland (non-coastal) pre-Saharan regions of Roman Africa. The discussion makes use of ceramic evidence, to work alongside the chapters by Leone and Leitch $e t$ al. in this volume, in order to reconstruct the directions and chronology of commercial networks across the Mediterranean coastline and the desert zone.

We are in fact much better informed about African pottery and amphora trade in the Mediterranean, and even in the Saharan region (e.g. in Fazzan), than on the distribution and the production of these artefacts in inland pre-desert areas of Roman Africa. Only a small number of excavations and surveys, including a few towns, ${ }^{1}$ a number of rural sites $^{2}$ and several military settlements, ${ }^{3}$ have been carried out (and published) in the high plains of Algeria, the high steppes of Tunisia and the pre-desert regions of Libya (Figure 12.1). The overall picture that emerges of the ceramics collected at these sites is completely different from the pattern evidenced in the Mediterranean, in the African coastal sites, and even in Fazzan. As noted by Elisabeth Fentress, who worked both on urban and rural sites in the Algerian high plains, two key factors characterise these remote places: amphorae are rare and local productions of pottery including (mostly late) ARS, dominate everywhere. ${ }^{4}$ Extending this model

In Algeria: Setif (Février 1965; Guéry 1970; Fentress 1991), Lambaesis (Amraoui and Bonifay forthcoming), Tebessa (Lequément 1968). In Tunisia: Haïdra (work in progress by C. Huguet see also Jacquest 2009).

In Algeria: Diana Veteranorum and Belezma region (Filah 1986; Fentress et al. 1991; Fentres 2013). In Tunisia: Kasserine region (Neuru 1987; 1990). In Libya: Central Tripolitania (Dore 1996; Hayes 1984)

In Tunisia: Guery 1986. In Libya: Bu Nijim (Rebuffat et al. 1967; 1970a; 1970b; Rebuffat 1997), alQurayyat al-Gharbiya (Mackensen et al. 2010; 2011; Schimmer 2012; Weber and Schmid 2012). For example, studying a context at Setif of the first quarter of the fifth century, E. Fentress noted: 'un manque général d'amphores à Sétif (Fentress 1991, 202). Belezma survey: 'in general the pottery all seems to have been locally produced' (Fentress 2013, 324). 


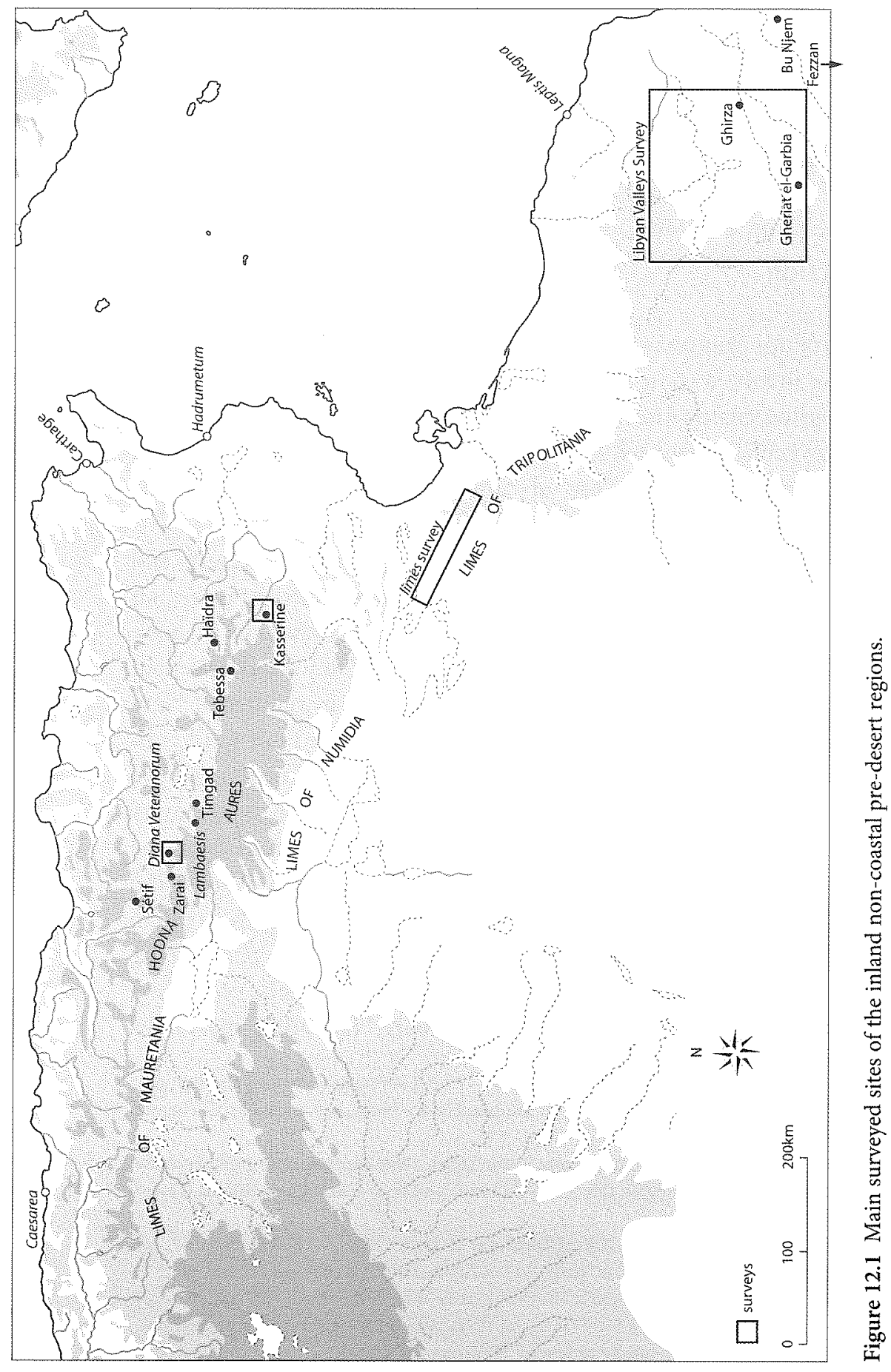

to central Byzacena and Tripolitania, she pointed out that 'mainstream' ARS imports were scarce in inland regions of Africa, and, following an idea made first by Bruce Hitchner, ${ }^{5}$ she suggested using the concept of 'import substitution' in order to refer to the local productions of ARS. ${ }^{6}$ A first attempt to globally apply this concept to amphora, fineware and wine production in Africa was recently undertaken by Karen Heslin. ${ }^{7}$

The implications of such a concept in terms of interconnections between the African provinces, the economic growth of the inland regions of Africa or the social integration of the populations living in these areas are significant, and they need to be studied in relation to a chronological canvas (as Leslie Dossey did in her North African study). ${ }^{8}$ Three key questions need to be addressed: Is the relative weakness of African/ Mediterranean imports in the inland and pre-Saharan regions of Africa due to a lack of local demand caused by social inequality and/or a cultural resistance, or more simply is this a consequence of high transaction costs implied by terrestrial transport? Is the development of local productions of tableware and containers a sign of reinforced integration into the Roman economy or, on the contrary, of the reinforced autarchy of continental Roman Africa? As far as pottery is concerned, how does the ratio between mports and local productions evolve in the inland regions of Africa, according to the chronology and the presumed social status of the different settlements?

My intention here, in order to further the discussion, is twofold. I will first examine the different possible forms of 'import substitution' of pottery and amphorae in the inland regions of Africa, and then try to find some basic keys to understanding this phenomenon.

\section{Ceramic Imports and 'Import Substitution' in Pre-Saharan Regions}

When studying ceramic artefacts, it is always worth distinguishing between tableware and containers. Of course, this distinction is less important for terrestrial trade than for maritime trade: within maritime trade, tablewares can be considered as a proxy for high-value goods, while they are more probably commercialised for their own value when moved overland. On the other hand, amphorae were the normal method for transporting liquid

${ }^{5}$ Hitchner 1993, 504 and n. 25. $\quad{ }^{6}$ Fentress et al. 2004, 147, 150, 157. $\quad{ }^{7}$ Heslin 2010. ${ }^{8}$ Dossey 2010, Part 1. 
foodstuffs by sea during Antiquity, and were not well adapted for terrestrial transport. Both these preliminary considerations can explain, at least in part, the specificity of the ceramic range found at inland Africa settlements.

\section{Fineware 'Import Substitutes'?}

The hypothetical 'import substitutes' often are simply defined in opposition to mainstream ARS productions. However, instead of a simple binary distinction between large-scale products and other African wares, I would propose distinguishing three main groups of ARS (Figure 12.2).

Group 1: ARS for (Mainly) Overseas Export

For the two authors already mentioned, ${ }^{9}$ and for most archaeologists working on the economic and social significance of ARS distribution, the ARS par excellence is that originating in northern Tunisia. The two main categories are: ARS 'A', dating from the end of the first century to the fourth century, although declining from the mid-third century onwards, and its successor ARS ' $D$ ', starting in the second quarter of the fourth century and lasting at least until the Arab conquest. Although no workshops for category A have yet been recognised, it is highly probable that this category, the first in date, was produced in the region of Carthage. ${ }^{10}$ On the other hand, the most prominent workshops of the late category D (El Mahrine and Oudhna) were located within a $40 \mathrm{~km}$ radius around the North African metropolis Categories A and D have been largely exported overseas. Category A is well attested in the inland regions of Africa, but category D is not, except some rare forms dated from the end of the fifth to the mid-sixth century.

Located in the northern part of the Gulf of Hammamet, the ARS workshop of Sidi Khalifa (ancient city of Pheradi Maius), was active from about the mid-fourth to the second half of the seventh century, ${ }^{11}$ with a floruit during the Vandal period. Being stylistically influenced both by the northern and the central Tunisian workshops, the production has been called ' $\mathrm{C} / \mathrm{D}$ '. ${ }^{12}$ Although the rural sites of the Segermes region were mainly supplied with these products, ${ }^{13}$ Sidi Khalifa cannot simply be considered as a local ARS workshop ${ }^{14}$ since its production was also widely distributed throughout the Mediterranean, but not, it seems, in inland regions of Africa.

9 Fentress et al. 2004, 156-57, and fig. 11.25; Dossey 2010, $44 .{ }^{10}$ Bonifay et al. 2012, 46 11 Ben Moussa 2007, 132-215, 12 Bonifay 2004, 49.

${ }^{13}$ See A. Leone, Chapter 13, this volume. ${ }^{14}$ As stated by Dossey 2010, 73

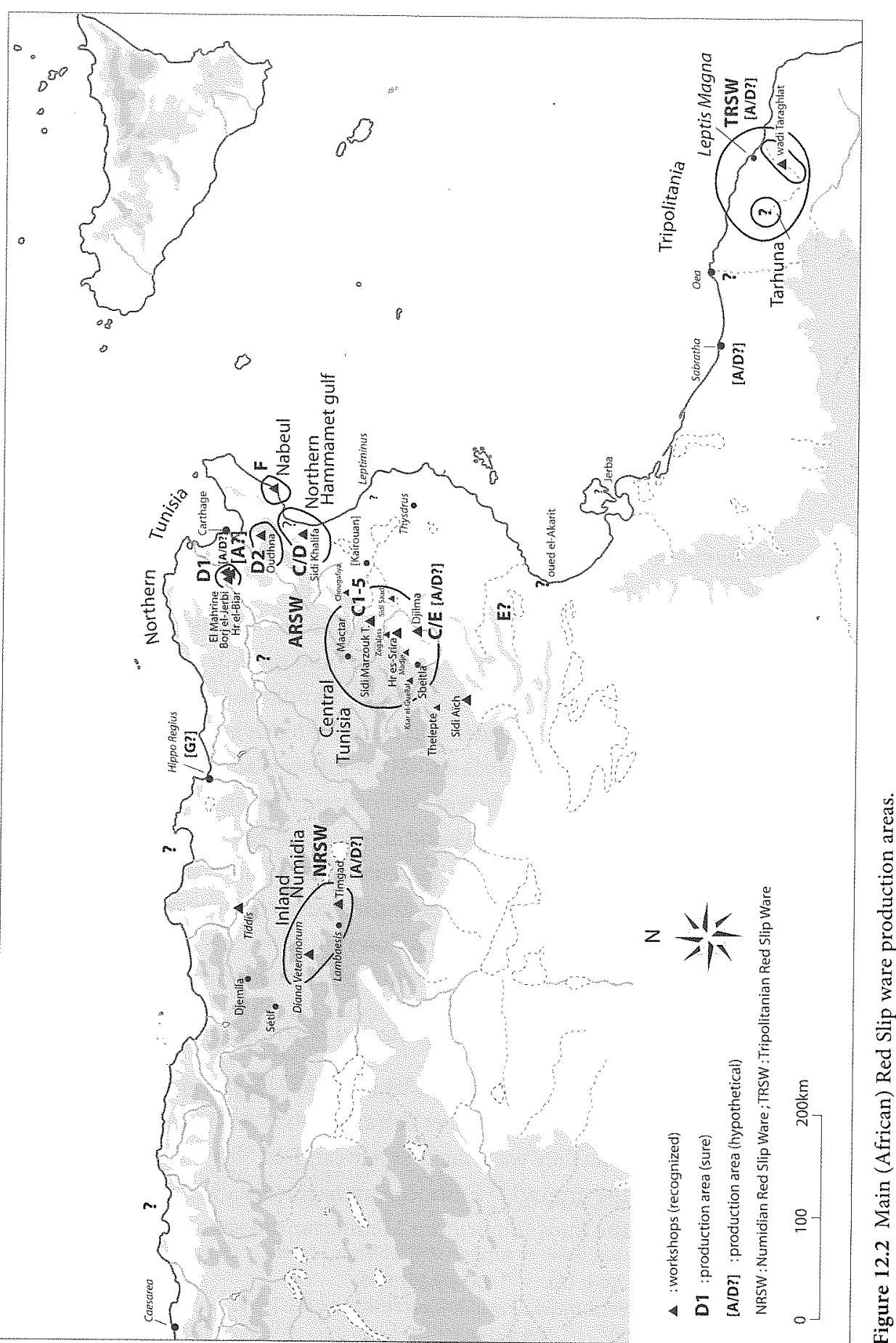


An interesting issue is raised by category $\mathrm{C}$, which was produced from the first quarter of the third century to the mid-sixth century and beyond in central Tunisian workshops, situated $100 \mathrm{~km}$ from the coast. This category has been interpreted as a sign of the economic development of Byzacena, ${ }^{15}$ or a response to the third-century crisis affecting northern Tunisian production. ${ }^{16}$ However, I do not think that ARS ' $\mathrm{C}$ ' can be considered as a true 'import substitute', because its distribution clearly is pan-Mediterranean. Moreover, due to its very high quality, at least at the beginning of its production, ARS ' $\mathrm{C}$ ' is not like the other categories which 'competed' with other ceramic-tablewares, but was something intermediate between ceramic-, glass-, and metal-tableware. As a result, perhaps, of the continental location of its production area, ARS ' $C$ ' was also distributed in the inland regions of Africa, though not regularly before the mid-fourth century, as we will see later on

The last category, sometimes classified as a mainstream ARS production, sometimes as an 'import substitute', depending on the authors, is category ' $E$ '. According to the geographical concentration of its finds in Tunisia, this ware was, between the mid-fourth and mid-fifth century, probably produced in southern Byzacena, although only one workshop has been identified as yet. ${ }^{17}$ Although its distribution in the inland regions of Africa is obviously significant, in some cases very far west, ARS ' $E$ ' was also distributed in the Mediterranean, mainly in the eastern part and the Adriatic. Such a distribution pattern, and also the high degree of standardisation of its production, make me reluctant to consider it as a simple local 'import substitute'.

In short, I remain largely faithful to the distinction suggested by John W. Hayes between the mainstream ARS wares, probably 'primarily intended for [overseas] export', ${ }^{18}$ and another group of tablewares which 'did not achieve the same widespread popularity' ${ }^{19}$ and that he called 'other African wares'. This second group can be subdivided according to differences in the distribution of each category, as follows.

\section{Group 2: ARS for (Mainly) Continental Distribution}

The first two categories included by John W. Hayes in his 'other African wares' group are the Henchir es-Srira and Sidi Aïch products. It is noteworthy that while they were the first African Red Slip ware workshops to be identified on the ground, ${ }^{20}$ European archaeologists were unable to identify them among the finds of northern Mediterranean sites. This paradox is due

${ }_{17}^{15}$ Fentress et al. 2004, 150. ${ }^{16}$ Dossey 2010,89. ${ }_{19}^{17}$ Henschir el-Guelal Djilma: Peacock et al. 1990, 76-79. ${ }^{18}$ Fentress et al. 2004, 155. to the very particular non-Mediterranean distribution of these workshops, which was not only local, but also widely continental.

Towards the east, the Henchir es-Srira and Sidi Aïch products are attested, for example, as far as Lepcis Magna, ${ }^{21}$ and along the bank of Little Sidra, ${ }^{22}$ but sherds attributed to one or other of these workshops in overseas consumption sites are rare or dubious. ${ }^{23}$ On the other hand, the Henchir es-Srira and Sidi Aïch products were widely distributed westwards, as far as Tebessa and the region of Diana Veteranorum in Algeria. ${ }^{24}$ Together with the ARS ' $E$ ' already mentioned, these southern Byzacena products were probably intended for exportation to the inland regions of Africa. Both these workshops were active from the third century onwards, with their main development in the fourth to fifth centuries. ${ }^{25}$

\section{Group 3: ARS for (Mainly) Local/Regional Distribution}

ARS production for local/regional distribution is a multi-faceted phenom enon, which includes the peripheral Tripolitanian and Numidian Red Slip wares, a multitude of local ill-defined productions in Western Byzacen and Eastern Numidia, as well as the ubiquitous category A/D

\section{Peripheral Workshops of Tripolitania and Numidia}

Tripolitanian RS ware is an interesting case. In the debate as to whether TRS productions appeared only in the fourth century or already in the second half of the third century, it is important to note that this tableware is closely linked to the cookingware 'BT' of the Lepcis Magna region. ${ }^{26}$ Both have the same fabric, and also the same external appearance; they were produced in the same workshops. ${ }^{27}$ This means that the first TRS wares, at least until the mid-fourth century, were not slipped, but only carefully polished. The slow shift of this ceramic production into a true fineware only occurred at the end of the fourth century and fundamentally distinguishes this 'ARS' production from the ones previously examined. This ware was produced until the first half of the sixth century. ${ }^{28}$ Only exceptionally exported to Mediterranean sites (a few pieces have been found in Sicily and southern Italy), ${ }^{29}$ TRS had a

${ }^{21}$ Bonifay and Capelli 2013, fig. 21.42 (Henchir es-Srira).

${ }^{22}$ Bonifay et al. 2002-2003, fig. 7.67 and 68? (Sidi Aïch). ${ }^{23}$ Quaresma 2010

${ }_{22}^{24}$ Bonifay 2013, 546; Nasr 2005

${ }^{25}$ For these two workshops see: Ladhari-Labayed 2007 (Henchir es-Srira) and Nasr 2005 (Sidi Aïh).

${ }^{26}$ Bonifay and Capelli 2013. ${ }^{27}$ Felici and Pentiricci $2002 . \quad{ }^{28}$ Kenrick 1985, 387.

${ }^{29}$ Hayes 1972, 304; Kenrick 1985, 394; personal observations (Sicily). 

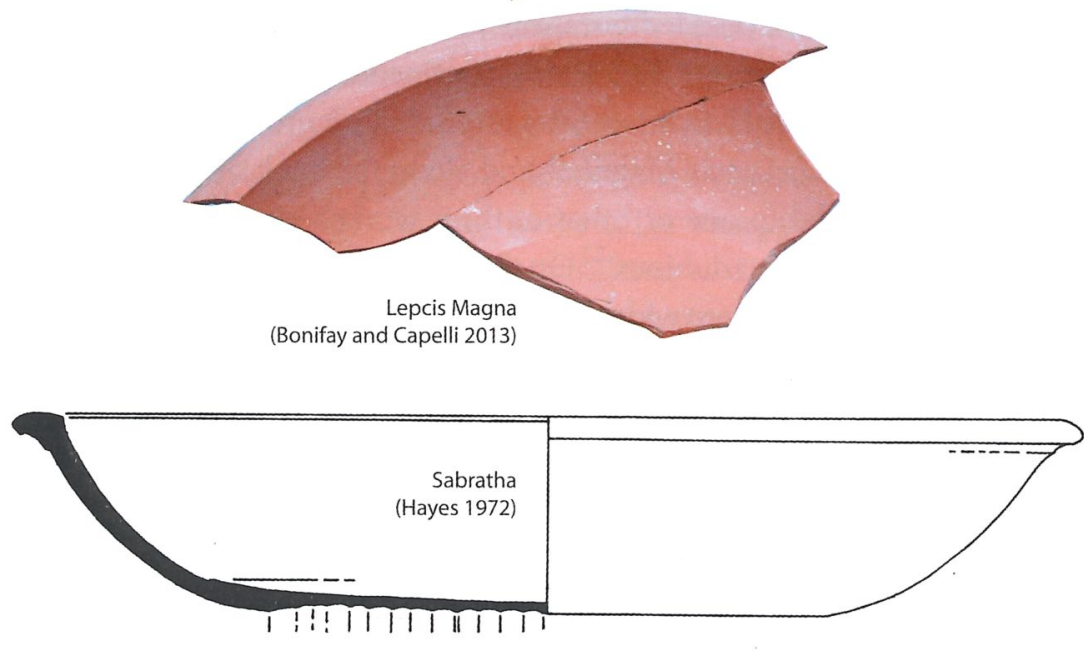

Hayes form 2 $5 \mathrm{~cm}$

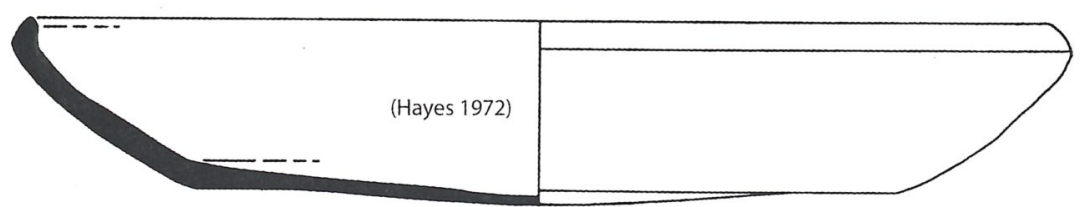

Hayes form 3

Figure 12.3 ARS 'import replacement': Tripolitanian Red Slip Ware (drawings from Hayes 1972; picture by author).

more eastern ${ }^{30}$ than western ${ }^{31}$ coastal distribution, and also reached central and western Roman Africa (there are some possible sherds in the Kasserine survey $^{32}$ ) (Figure 12.3).

The production recently called 'Numidian RS' by E. Fentress ${ }^{33}$ is also emblematic of what we imagine an 'import substitution' could be. ${ }^{34}$ The typological portfolio is very simple, and includes only two forms: a flanged bowl (form A according to John W. Hayes), and a shallow dish with chamfered rim (form B). ${ }^{35}$ The firing of this ware was done in an open fire, without saggars, as demonstrated by the blackening of the external rim, in the same manner as the Black-top cooking wares of the Carthage region. Nevertheless, the slip was of good quality, and a stamped

${ }^{30}$ As far as Benghazi and Tocra: Kenrick 1985,387

${ }^{31}$ See Leone about the Jerba survey, Chapter 13, this volume. ${ }^{32}$ Neuru 1987.

(2013.

35 Hayes 1972, 303. I suggest that form C does not belong to the same production. decoration was also present. As already stated by John W. Hayes, Numidian RS ware is the normal fine ware in fourth- to fifth-century contexts at Setif, but also throughout the Algerian high plains; a workshop was identified at Diana Veteranorum. ${ }^{36}$ Numidian RS does not seem to have been exported outside its production region.

\section{Local Productions of Western Byzacena and/or Eastern Numidia}

Numerous series of sites, from the Algerian high plains to the Tunisian high steppes, and from the upper Mejerda valley to the limes tripolitanus, provide a limited range of ill-defined ARS productions, quite heterogeneous in the make-up of their fabric, but also very uniform from a typological point of view. Other than numerous, sometimes unslipped, flanged bowls, two forms are typical of these productions. The first one is a deep flat-bottomed dish with an internally thickened rim (from Hayes 1972, fig. 58b). There are no comparable forms in the other ARS productions, and this was perhaps inspired by local, even handmade, pottery traditions; it is frequent in fourth to fifth century contexts. ${ }^{37}$ The second form is a deep dish with an incurved rim and a ring foot (Hayes 1972 Figure 58a), not too far from the typology of certain third-century ARS ' $A$ ' or 'A/D' dishes (types Hayes 27 or 27/31) (Figure 12.4).

\section{ARS 'A/D': A Ubiquitous Production?}

ARS 'A/D' is not an easy category. Geochemical and petrographical analyses point to a multiplicity of production centres, in Tripolitania (where at least two different groups have been identified), in central and perhaps northern Tunisia, and even in Algeria (Figures 12.5-12.6). Thus ARS 'A/D' appears to form the common core of the African Red Slip ware of the third century, ${ }^{38}$ produced by numerous workshops spread over a large territory, only a few of which exported their products overseas.

The analysis recently performed on the Sicilian finds did not allow for the identification of the workshops exporting their products outside Africa, even if Byzacena is a strong possibility, and Tripolitania cannot be excluded. But more interesting for our purposes is that the majority of the products we classify within the category 'A/D' were not set aside for Mediterranean distribution, but were made to satisfy African regional

${ }^{36}$ Fentress et al. 1991, 111-12. ${ }^{37}$ Bonifay 2013, 547 and note 72, with bibliography. ${ }^{38}$ Bonifay et al. 2012, 47. 


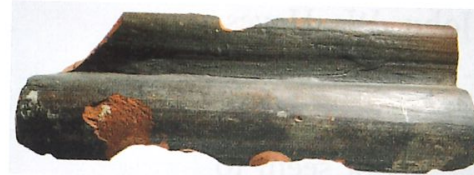

cos ref.coll.

$\stackrel{0}{2}$ $5 \mathrm{~cm}$

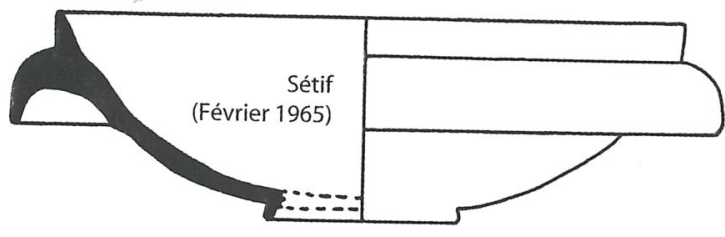

Hayes form A

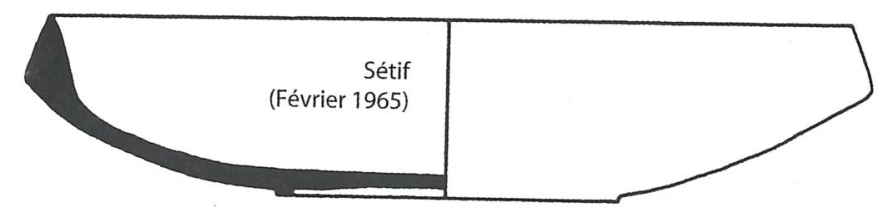

Hayes form B

Figure 12.4 ARS 'import replacement': Numidian Red Slip Ware (drawings from Février 1965; picture by author).

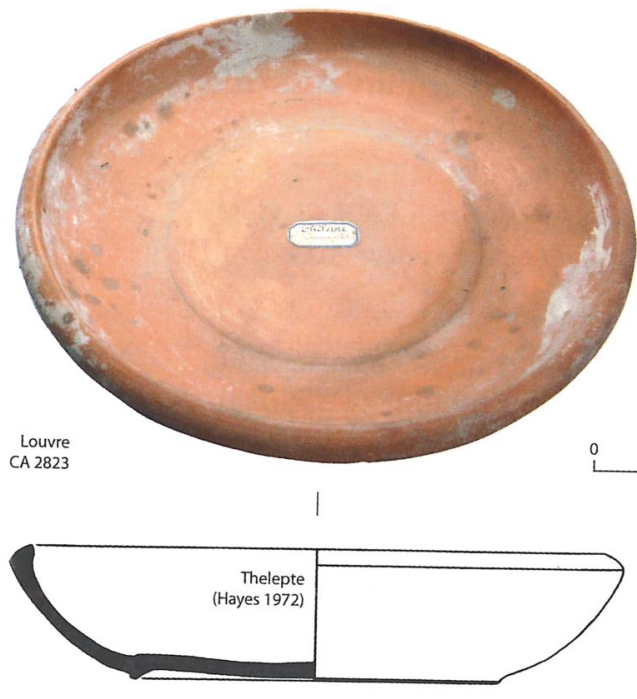

Hayes 1972, fig. 58a

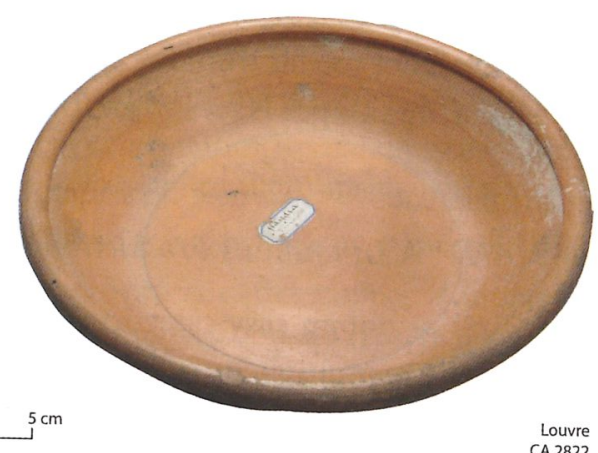

$\underset{\text { Louvre }}{\text { CA28282 }}$
Figure 12.5 ARS 'import replacement': Red Slip Ware of South-Western Byzacena/ Eastern Numidia. Paris, Louvre museum, Department of Greek, Etruscan and Roman Antiquities. Inv. CA 2823 and 2822, from Thelepte and Haïdra. Goetschy's purchase (drawings from Hayes 1972; pictures by author)

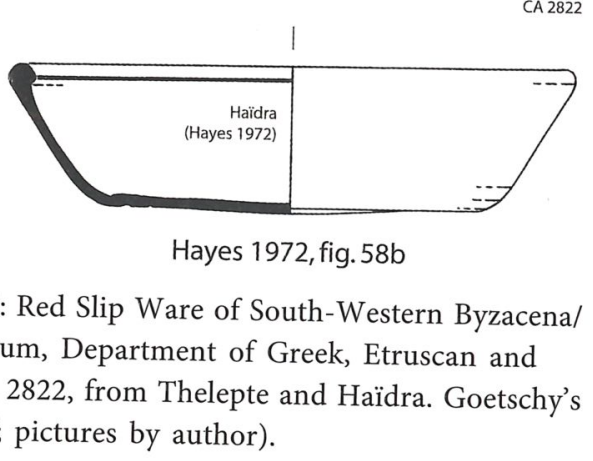




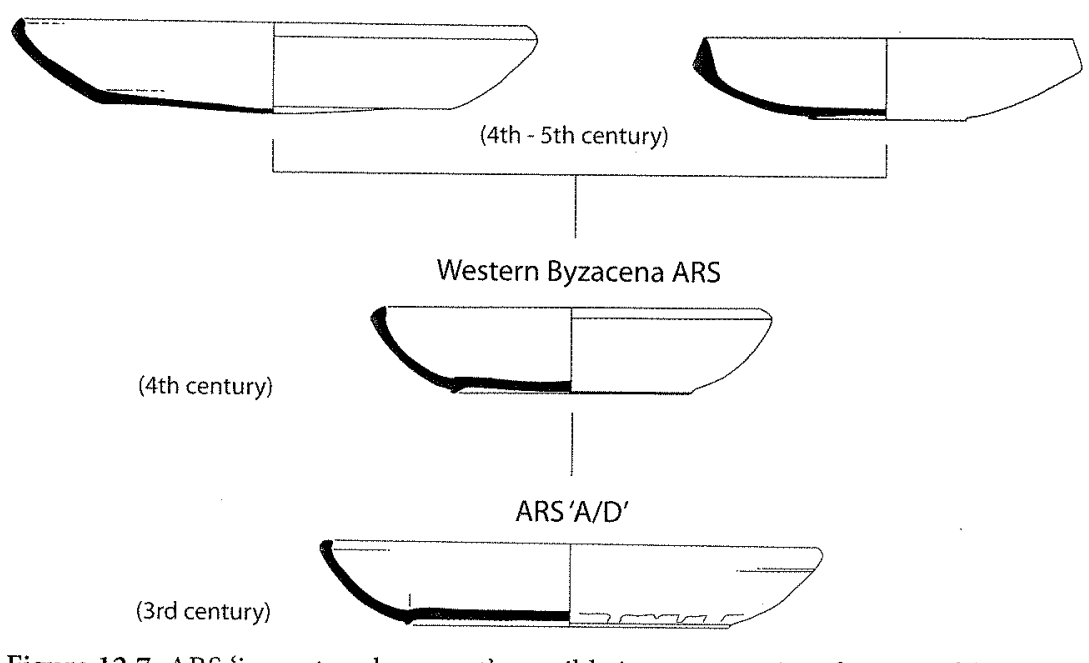

Figure 12.7 ARS 'import replacement': possible interconnections between fabrics and forms (reworking by author).

In conclusion, I propose a much more restricted definition of ARS 'import substitution' than previously stated, but also a slightly earlier apparition, by the end of the second century or the beginning of the third century, of these products in inland regions of Africa.

\section{Amphora 'Import Substitutes'?}

In inland regions of Africa, most of the amphorae are not transport amphorae. These large containers, with a generic transport amphora shape, typical of both Greco-Roman and Neo-Punic types, were for food storage and did not move. ${ }^{39}$ Nevertheless, we can identify three other categories of containers used for the transportation of foodstuffs.

\section{Rare Imported Amphorae}

The rule in the inland regions of Africa is that amphorae are rare or even absent from the mid-first century onwards. ${ }^{40}$ This is reflected in the pottery

${ }^{39}$ Four examples have been recently found in the third century destruction levels at the 'Maison de la Tigresse' in Lambaesis.

The only periods when some Mediterranean amphorae do reach the inland regions of North Africa, are during the Late Republic and Early Empire, with the imports of Italian wine (Dresse 1 and 2/4) and Spanish fish (Dressel 7/11): examples are recorded at Ain Wassel, Ucchi Maius and Maktar. at Setif and in the rural settlements of the Algerian high plains, ${ }^{41}$ and to a lesser extent in the Kasserine survey. ${ }^{42}$ The situation may have changed during the fifth century and the first half of the sixth century. At Timgad, fifth-century Spanish amphorae have been found. ${ }^{43}$ At Tebessa, two exemplars of fifth-century Keay 8B amphorae are displayed at the Ancient Church Museum. Among the Late Roman amphora sherds collected during the Kasserine Survey, the only securely identified ones are also Keay $8 \mathrm{~B} .{ }^{44} \mathrm{As}$ far as the quantity of amphorae is concerned, the situation is not completely different in central Tripolitania (Libyan Valleys Survey), where only a hundred amphora sherds were collected compared to 1800 sherds of ARS. ${ }^{45}$ In this region, the main bulk of amphorae are Tripolitanian, but their quantity drops drastically from the end of the fourth century onwards while the importation of Tunisian amphorae remains stable. ${ }^{46}$

There is at least one exception, in Lambaesis. A fire layer in a house burnt in the mid-third century provides a large assemblage of amphorae of various origins: ${ }^{47}$ Lusitania, Gaul, Campánia, northern Adriatic, Sicily, Crete, Aegean sea, Asia Minor (Ephesus and Cnidus), Tripolitania. Sicilian amphorae are the most numerous with 17 exemplars of type Benghazi Mid-Roman 1. The vast majority of these amphorae transported wine, some of which was high quality like the Campanian wine transported in the late variant of type Dressel $2 / 4$.

\section{Amphorae for Local Distribution}

Small, probably multi-use, globular amphorae, with handles attached on the neck or on the shoulder, are known at sites in the Algerian high plains. ${ }^{48}$ In Lambaesis, in the mid-third-century abandonment context, a new type of local amphora was identified (Figure 12.8). ${ }^{49}$ This new type is influenced by the shape of the Sicilian amphorae well represented in the same context, and in consequence was probably for the transportation of wine, either locally produced or imported in bulk.

${ }^{41}$ Fentress 2013,324.

Defore the fifth century.

3 Bonifay 2013, 536

Neuru 1990, 259 and figs. 16.j, 1 and o? This type could be considered as local because its production is already attested in the nearby region of Gafsa: Bonifay 2004, 31 and fig. 14 (Majoura workshop). The sherd illustrated on fig. 16.k is rather a 'Keay 1984, fig. 172.2' than Keay $8 \mathrm{~B}$, but could be of the same origin.

${ }^{45}$ Dore 1996. Dore 1996, fig. 4\%.1. Amraoui and Bonifay, forthcoming

${ }^{48}$ Bonifay 2013, fig. 1.2-3. ${ }^{49}$ Amraoui and Bonifay, forthcoming. 


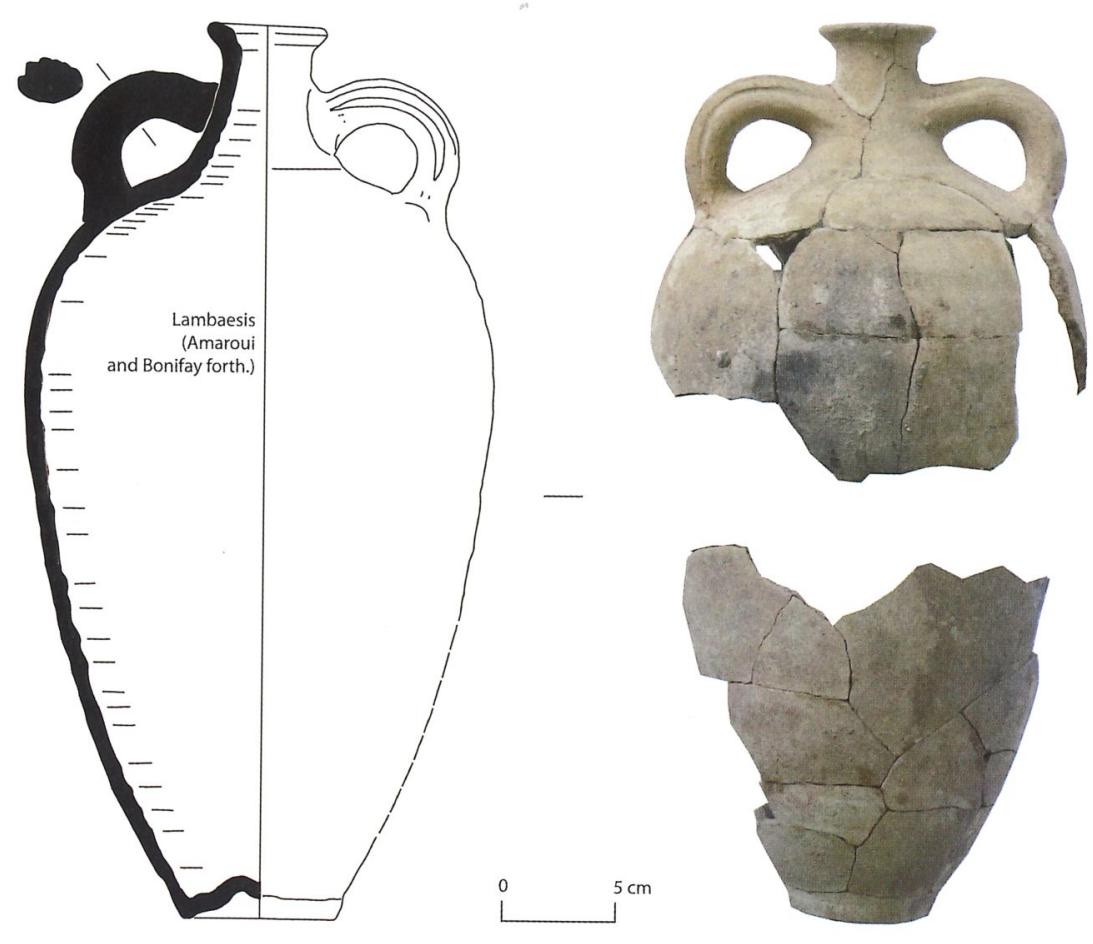

Figure 12.8 Amphora 'import replacement': local wine? amphora from Lambaesis (from Amraoui and Bonifay forthcoming).

\section{Barrels and Skins}

The use of skins and barrels is well documented in Africa. ${ }^{50}$ The most ancient representation of a barrel is known on a stele of Thala not far from Haïdra, while some ARS 'A' jugs are shaped in the form of barrels or skins. Skins also appear on the decoration of ARS ' $\mathrm{C}$ ' bowls and lamps, some of which are shown being carried by camels. Skins (and barrels?) probably were the normal mode of transport for liquid foodstuffs in the inland and non-coastal pre-Saharan regions. The distribution of such containers, although only recorded by the iconography, could reflect the development of an 'import substitution' production of local olive oil and wine, ${ }^{51}$ and perhaps also explains the archaeological invisibility of imported Mediterranean wines and seafood products (garum).

${ }_{51}^{50}$ Marlière and Torres Costa 2007.

See Brun 2003. Mention of a probable production of wine in Lambaesis: Lequément 1980, 187. Grape pollens were found at press sites on the Kasserine survey (personal communication by B.
Hitchner).
Interpretation: Concept, Chronology and Comparisons with

\section{Saharan Regions}

Three main questions need to be raised: To what extent is it legitimate to apply the concept of 'import substituition' to the economy of the inland regions of Roman Africa, and how far is it helpful for understanding the development of this area? Is it possible to reconstruct the chronological phasing of this process of development? Did or did not this model interact with the economy of the Saharan regions?

\section{Validity of the Concept of 'Import Substitution'}

As usual, there is a gap between concepts elaborated for our modern economy, and the real possibility of their application to the Roman economy. Is it legitimate to apply the concept of 'import substitution' to the economy of Roman Africa inland regions? Did this model of development interact with the more developed coastal regions? Were all the populations affected by this phenomenon?

\section{'Import Substitution' or 'Import Replacement'?}

Even if it seems well established that, from the third century onwards, local production of tablewares and non-ceramic containers tended to replace ARS and amphora imports in the pre-Saharan regions of Africa, this phenomenon of 'import substitution' cannot have had the same significance as today. Nowadays, the 'import substitution' theory, more frequently named 'import substitution industrialisation' (ISI), is an economical strategy implemented by governments for accelerating the development of a underdeveloped region or country. Applied to the Roman local economy, and to artefacts of limited economical importance (tablewares), this concept is more commonly considered as one indicator, among others, of economic growth ${ }^{52}$ or development. ${ }^{53}$

However, tableware 'import substitutes' of the third to fourth century in inland Africa may have faced similar problems as the locally manufactured products generated by an ISI policy, and which can cause this policy to be turned upside down. First, poor technology could make it difficult for the

${ }^{52}$ Hitchner 1993, 504 and n. 25.

${ }^{53}$ For the followers of ISI politics, there are ways for communities to develop without growing and one of those ways is through import substitution. 
local manufacturers to provide high-quality import substitutes and meet the tastes of the customers. Second, the same low technology and small scale of production could lead to high production costs, and make imported goods cheaper than locally made counterparts. The first issue can be seen in the production of Numidian RS, which was not fired in saggars (and therefore had a blackened rim), and the first Tripolitanian RS which were not slipped, and the very poor-quality products of the Tiddis workshops - but these technical faults did not prevent their local distribution. On the other hand, if the very low price for the maritime transport of tablewares, alongside the transport of high-value foodstuffs, could explain the extensive distribution of ARS in the Mediterranean, and made any attempts at tableware 'import substitution ${ }^{54}$ pointless, it was not the same in inland Africa, where the possible higher production cost of local tableware could easily be offset by the reduction of terrestrial transport costs.

As an alternative, if we don't want to see the imperial or provincial authorities involved in this development process of local manufacturers, the concept of 'import substitution' might be shifted towards the related concept of 'import replacement', put forward by Jane Jacobs. ${ }^{55}$ In a modern sense, the notion of 'import replacement' refers to an urban free market economy with entrepreneurs replacing the imports of the city with productions from within the city. This concept makes sense if we consider that the few examples of local ARS workshops in the pre-Saharan regions (except in Tripolitania) were located on the outskirts of towns, for example in Diana Veteranorum, Timgad, Thelepte, Sidi Aïch, Henchir es-Srira, etc

\section{'Import Replacement' vs. 'Export-Oriented' Production?}

What group 1 ARS shows us, as stated by Chris Wickham, ${ }^{56}$ is 'a set of productions, substantially for export, focused on separate routes to the coast, and not interconnecting internally'. All these workshops were leaning against the Tunisian dorsal, looking east or north-east, with different port facilities. Their distribution pattern was primarily Mediterranean, with accompanying products of high-value foodstuffs (especially grain). Located in the same region, group 2 ARS workshops were distributed both along the immediate coastline and in the very far inland regions of Africa. These products could inform us about trade from the coasts to the inland regions of Africa, of which very little archaeological evidence still remains

${ }_{54}^{54}$ At least until the beginning of the fifth century. ${ }^{55}$ After Jacobs 1969. ${ }^{56}$ Wickham 2005, 721 . (except the tariff of Zaraii). Lastly, group 3 ARS corresponds well to the socalled 'import replacements'. It is the only group that was not regularly exported beyond its region of production.

Groups 1 and 2 on the one hand, and group 3, on the other, seem to follow different economic flows. Using modern and perhaps anachronistic notions, we could say that the first groups follow an export-oriented strategy, while the second only attempts to connect local demand with local supply. Such differences in the strategies of production of similar artefacts provide another argument favouring the idea of the coexistence of several levels in the Roman economy. Although groups 1 and 2 were also locally distributed and group 3 occasionally exported, each of the three groups of ARS could fundamentally correspond to one of the three different economic structures (imperial, interprovincial, and provincial economies) defined by David Mattingly. ${ }^{57}$

Nevertheless, especially in a demand-driven economy, consumers could make the difference. Not everyone had the same needs and incomes: some were content just to meet their needs, while others sought additional goods. ${ }^{58}$

\section{'Import Replacement' and Inequalities}

Recent research on the Roman economy and society has focused on the heterogeneity of living conditions among the inhabitants of the Roman Empire. Notions of Romanisation, colonialism, inequality, identities, resistance, etc. have been revisited, ${ }^{59}$ allowing for the emergence of a more complex picture of the Roman world to be created. Thus, even if the process of ceramic 'import replacement' is obvious in inland Africa, it did not affect all the inhabitants of these regions on the same scale.

The most striking example is given by the amphorae. The wide range of imported amphorae found in a mid-third-century destruction context in Lambaesis is probably due to the status of the town, as the capital of the Numidia province and headquarters of the III Legio Augusta, and of its inhabitants, mostly soldiers, whose substantial income permitted them to acquire high-value imported goods. In addition, it is perhaps no accident that local imitations of Mediterranean amphorae were also produced in that very city. The rarity of amphorae in the other sites of the Algerian high plains, including the city of Setif, does not imply that wine was not

${ }^{57}$ Mattingly 2011, 138-140. See also Leveau $2014 . \quad{ }^{58}$ Greene 2008, 66.

${ }^{59}$ All of them being encompassed within the concept of discrepancy by D.J. Mattingly (2011). 
consumed or even imported. But in this case, the normal containers were skins and perhaps barrels. ${ }^{60}$ Furthermore, at the beginning of the third century, the Zarai tariff specifying the transit price of wine and garum by 'amphora' may refer to a unit of measurement, rather than the object it was transported in. In short, the possible replacement of amphorae by skins or barrels as the most common method of commercialisation of imported wine or garum, could have allowed for the widespread distribution of these commodities, but for those with plenty of money, acquiring these products in their original packaging was a sign of social prestige. ${ }^{61}$

ARS is also a good indicator for inequality in society, and additionally its distribution patterns in urban areas and large farms (where it is supposed to have been common) were quite different from patterns in small rural and mountain settlements (where it is claimed to have been rare or absent). According to Leslie Dossey, the low levels of rural consumption of (imported) ARS before the fourth century can be explained by a lack of peasant demand due more to an extreme frugality imposed on these populations by the ruling classes, than to a form of cultural resistance against Roman imperialism. ${ }^{62}$ Still, following this author, it was not until the fourth century that the development of local artisanal industries permitted ARS 'to become the tableware of the poor'. I am not convinced that a lack of consumption of ARS must be considered as a criterion of 'frugality', 63 or that the sedentary nature of the sites does not in part explain the rarity of second century sherds at the soil surface, ${ }^{64}$ but the general trend is probably right. I would, however, like to raise a chronological issue. As demonstrated at the Lambaesis excavations, as well as during the survey conducted in the region of Diana Veteranorum by Mustapha Filah in the 1980 s, a great deal of the ARS formerly interpreted as late ARS D or more recently as late local Numidian RS, are in fact local productions of the so-called category $\mathrm{A} / \mathrm{D}$, to be dated to the third century. The same observation can be made for southern Tunisia, in the limes tripolitanus settlements explored by Pol Trousset ${ }^{65}$ In this case, what ARS tell us is that imports were not rare during the second century, at least in the cities, ${ }^{66}$ and that from the beginning of the third century onwards local productions had already taken hold everywhere.

On the importance of skins and barrels in Roman Africa, see Marlière and Torres Costa 2007. A second-century portorium inscription of Lambaesis refers to Italian and Greek wines, and to (African?) table wine (vinum cibarium) of lower quality (Lequément 1980, 187).

${ }_{65}$ Dossey 2010, 58. ${ }^{63}$ Dossey 2010, 60. ${ }^{64}$ Fentress et al. 1991, 109.

${ }^{65}$ Trousset 1974; Guéry 1986. The material collected in 1974 (and stored in Aix-en-Provence) has ${ }_{60}$ been recently re-surveyed by V. Leitch and $m$

${ }^{66}$ Example of Setif: Guéry 1985.

\section{Chronological Phasing of the 'Import Replacement' Process}

The end of the Antonine period and the beginning of the Severan period saw the displacement of the African productive force from the Carthage region towards the Hadrumetum region, that is from the north to the south, reproducing in miniature a phenomenon of 'meridionalisation' of the productive force ${ }^{67}$ observed at the same time within the larger Mediterranean context. ${ }^{68}$ This new economical power in central Byzacena is archaeologically exemplified by the huge production of amphorae in Hadrumetum, Leptiminus and Salakata, as well as by the beginning of the mass production of ARS ' $\mathrm{C}$ '. This is also the moment when a series of workshops, largely unknown until now, began production of the ubiquitous so-called ARS ' $A / D$ '. The end of the second century to the beginning of the third century is the first step in the process of tableware 'import replacement' in remote regions of Roman Africa. At the same time, even if it is impossible to determine whether or not this is a cause or a consequence of the 'import replacement' phenomenon, mainstream (northern Tunisian) ARS no longer reached inland African sites. In the Setif necropolis, ARS ' $A$ ' is frequent with second-century forms (Hayes 3B $3 \mathrm{C}, 6 \mathrm{~A}$ and $\mathrm{B}, 8 \mathrm{~A}, 9 \mathrm{~A}$ ), while third-century forms are completely absent. ${ }^{69}$ In the Kasserine survey, the small quantity of ARS ' $A$ ' sherds all belong to early forms (Hayes 5, 6 and 8). ${ }^{70}$ In the Libyan Valleys Survey, thirdcentury ARS ' $A$ ' forms are not absent but are much less numerous than second-century forms. ${ }^{71}$ It is also interesting to note that the third-century forms in ARS ' $\mathrm{C}$ ' (e.g. Hayes 50A) are absent from the Numidian sites, and not numerous in the Kasserine and Libyan Valleys surveys.

A second phase takes place in the fourth century (the main chronological focus of L. Dossey's research). This is the moment when Tripolitanian RS moved from second-rank tableware, not very distinct from cooking ware, to a true fineware, and when the production of Numidian RS ware really started. This development comes on the heels of the birth of ARS ' $D$ ' in the region of Carthage, and coincides more or less with the apparition of ARS ' $E$ ' in southern Byzacena, as well as with the growth of the production in the Henchir es-Srira and Sidi Aïch workshops. Nevertheless, if ARS ' $\mathrm{C}$ ' and ' $E$ ' products, along with Henchir es-Srira and Sidi Aïch products, did reach the pre-Saharan region during the fourth century, Numidian sites,

67 Panella 1989, 133. ${ }^{68}$ Carandini 1983, 149

${ }^{69}$ Guéry 1985, 345-48. ARS 'A' of the 2 nd c. is also frequent in urban contexts: Guéry 1970, fig. 37 \& 38 (levels 6 and 7).

${ }^{70}$ Neuru 1987, 177-79. ${ }^{71}$ Dore 1996, 323. 
south-western Byzacenian sites and, to a lesser extent, central Tripolitanian sites were cut off from northern Tunisian ARS 'D1' imports.

Surprisingly or not, considering the state of the research today, it is hard to detect, in the 'import replacement' process, the same drop as observed in ARS distribution in the Mediterranean during the fifth century Production and distribution remain stable, although ARS imports, mainly from central Byzacena (ARS 'C5'), are more numerous. The end of local production in Numidia and Tripolitania does not seem to take place prior to the Byzantine (re)conquest or even a little bit after. In the inland regions of Africa, from the beginning of the sixth century onwards, we see just a few ARS 'D' imports, which become increasingly rare.

A varied pattern emerges when examining the amphorae. In Numidia and south-western Byzacena, the drop of imported amphorae seems to begin earlier, from the mid-first century onwards, but the imports increase again during the fifth century. However, in central non-coastal Tripolitania, the presence of regional Tripolitanian amphorae remains stable, although weak, until the end of the fourth century, before dropping considerably from the fifth century onwards.

\section{Comparisons with Saharan Regions}

This attempt to chronologically phase the 'import replacement' process in the inland and non-coastal pre-Saharan regions of Roman Africa prompts us to reflect on its possible economical impact in the Saharan regions. I will look at Fazzan and Egyptian routes to investigate this question.

\section{Fazzan}

There does not seem to be any tableware 'import replacement' production in Fazzan. Nevertheless, when examining the ARS imports, it is obvious that the only moment when northern Tunisian ARS are numerous in the Jarma region is the second century, with the arrival of numerous ARS 'Al' forms (nevertheless of poor quality), ${ }^{72}$ like Hayes $2,3 \mathrm{~B}$ and $\mathrm{C}, 4,5,6,8 \mathrm{~A}$ and $9 \mathrm{~A} .{ }^{73}$ Other mainstream ARS imports are very rare up to the end of the Roman/Byzantine period, ${ }^{74}$ while Tripolitanian import

72 See Leitch et al, Chapter 11, this volume.

Vere al. 2007, 332-33. Matholy 2013, 176-77.

Very few ARS C2: Mattingly 2013 notes only one Hayes 50 plate and one Hayes 44 bowl. One 5ample of C5 recorded by). Dore (Doret al, 2007, 333: Hayes 84). Few ARS 'D1': form Hayes 59A: Hayes 1972, 96, no. 1, fig. 15 and pl. XIIa (left); Mattingly 2010, 369 and fig. 6.33b. Form replacements' are well represented in the third and fourth century: ARS ${ }^{\prime} \mathrm{A} / \mathrm{D}^{175}$ and TRS. ${ }^{76}$ It was noted that this pattern could be distorted by uneven excavation and recording (most of the second-century ARS having been found in tombs). ${ }^{77}$ Nevertheless, there is a striking convergence between the situation in the pre-Saharan region of Tripolitania and the Saharan region with regard to fineware supply, ${ }^{78}$ demonstrated by the ceramic survey in Fazzan, ${ }^{79}$ and by a recent revision of the material from old excavations in Jarma. ${ }^{80}$

It is also interesting to compare the amphora import patterns. Most of the amphorae collected in Jarma are Tripolitanian types. But I am not sure that all the Tripolitanian types are represented in Jarma. I would say that the Tripolitanian types which have been recorded do not, with few exceptions, ${ }^{81}$ go beyond the chronological limit of the end of the second century. Tripolitana I can be identified, with some late variants${ }^{82}$, but hardly 'true' Tripolitana III. Tripolitana II is only represented by its classic second-century variant. ${ }^{83}$ That is not to say that amphora ceased to be transported to Fazzan from the third century onwards. As noted by Victoria Leitch in Chapter 11 the great bulk of 'Tripolitanian' amphorae found in Jarma are 'unusual forms', 'small and squat', perhaps 'produced specifically for desert trade' (Dore's Fazzan types 15, 22 and 26) ${ }^{84}$ In this case, we can perhaps detect another experience of amphora 'import replacement': forms specially made in the pre-desert regions for crossing the desert to supply Fazzan. Ongoing petrographical analyses will perhaps help us understand where these unusual amphorae

Hayes 76: Mattingly 2010, fig. 5.141. No form Hayes 61A?: according to Mackensen 1993, 319 the ARS Hayes $61 \mathrm{~A}$ plate, published by J.W. Hayes (1972, 101, fig. 16 and pl. XIIa, right) and lastly by D.J. Mattingly (2010, 369 and fig. 6.33a), might be considered a central Tunisian product rather than a northern Tunisian one. One 'D2' Hayes 96 bowl: Hayes 1972, 149, no. 7

product rather than a northern Tuis
Mattingly 2010, 364 and fig. 6.27 .

Hayes 17, 27/31, 31', 32, and 33 (Mattingly 2013, 176-177; Leone 2013, 330).

77 Hayes 2, 3, 4, 5, and 8 (Dore et al. 2007, 334-335; Mattingly 2013, 176-177).

As shown in the graphs published in Leitch et al., Chapter 11, this volume.

${ }^{78}$ Conclusion already stated in Leitch et al., Chapter 11 , this volume, with quantified graphs but less concern for ARS origin

${ }^{79}$ Mattingly 2013.

${ }^{80}$ First Libyan Pottery Workshop held at Leicester in July 2014 within the University of Leicester and Centre Camille Jullian cooperation framework.

${ }^{81}$ Bonifay 2013, 540, n. 38.

Dore et al. 2007, fig. 41.10-11, type 19: hollow foot (= not Tripolitanian III).

Dore et al. 2007, fig. 41.13, type 21; only n 1992 could be third century.

Dore et al. 2007, fig. 41.8, type 15; fig. 41.14, type 22; fig. 41.15, type 26. See also Leitch 2014, fig. 10 
are coming from. ${ }^{85}$ The question is how far these small amphorae, even if more adapted to transport by donkeys or mules than big amphorae, would have efficiently competed with the more normal use of skins (as well as barrels?) in terrestrial transport. In order to explain the presence of these strange 'desert amphorae', we should consider that ceramic containers may have been important for specific contents (such as fish sauce ${ }^{86}$ or even wine) and to protect the contents from the heat. We could also hypothesise that in this case the reuse of the containers (back and forth) could have played a more major role than in coastal regions. Everything happens as if Fazzan has been left out of the main (Mediterranean) amphora trade route along the limes at the end of the second century and the first half of the third century. ${ }^{87}$

In such a panorama, and without any information on possible fourth century imports, the presence of two exemplars of late sixth to beginning of the seventh century Tunisian amphorae in $\mathrm{Jarma}^{88}$ does not cease to astound, even if other Late Roman amphora imports are not completely absent from the inland regions of Africa. ${ }^{89}$

\section{Egyptian Routes}

In a recent collective survey of the African tableware and amphora imports to Egypt, ${ }^{90}$ we went back to the idea, already put forward ten years ago, of a possible transport of African goods by land routes. This hypothesis concerns two types of goods and two different periods. The first one is illustrated by the arrival of numerous Africana I and II amphorae in the oases of Siwa and Bahariya, which is difficult to explain through the classical model of return cargoes from Rome arriving at Alexandria: it would not have made sense to transport these amphorae from Alexandria to Siwa. The second example is about the much larger proportion of Vandal ARS 'C5' in the Nile Valley than in Alexandria during the fifth century; such a pattern does not fit in with the idea of transport by sea and then by river. In both cases, the hypothesis was that these goods had been

${ }^{85}$ Petrographic analyses carried out by Dr. Claudio Capelli (University of Genova/Centre Camille

Jullian).
${ }_{87}$ Leitch 2014, 123.

87 Well attested in Bu Nijim with a bulk of third century Tripolitana III and Africana II A

amphorae (Rebuffat 1997), and in al-Qurayyat al-Gharbiya with third century Dressel 30 from

${ }_{88}$ Nabeul and Benghazi MR 1 from Sicily (Schimmer 2012).

Mattingly et al. 2010, fig. 10a (Keay 61C/Henchir ech Chekaf II, from the Tunisian Sahel region, end sixth-beginning seventh century) and b (Keay 62A or I): huge capacity (up to $90 \mathrm{l}$ ), not

olive oil?

Bonifay 2013, 536. ${ }^{90}$ Ballet et al. 2012 transported by camels, using an ancestral caravan route across the Western Desert.

Such hypotheses are fragile, and hardly accepted by most of the scholars working on Trans-Saharan trade. ${ }^{91}$ The Bahariya oasis was linked to the Nile Valley through at least three different roads reaching Oxyrhynchos, the Fayum and even the present-day Cairo. Another hypothesis could take into account a possible primary maritime itinerary to Benghazi or Paraetonium, closer to Bahariya and Siwa than the Alexandria harbour. ${ }^{92}$

Nevertheless, the third-century route along the limes could also be interpreted as the extension east of the commercial 'bypass road' running along the Numidian limes, ${ }^{93}$ which perhaps permitted Lambaesis to be supplied by Mediterranean wine amphorae for its soldiers. Indeed, this route would have been a very secure one during the first half of the third century due to the presence of permanent garrisons in the oases of $\mathrm{Al}$ Qurayyat al-Gharbiya, Bu Nijim, and perhaps Awjila. ${ }^{94}$ The use of this road during the fifth century is more hypothetical, but it is worth noting that the transport by land of African tableware would have coincided with the disruption of the ARS supply by sea in the whole Eastern Mediterranean It also coincides with the main development, in the second half of the fifth century, of the production of Egyptian Red Slip ware 'A' in Aswan, which considering the very close imitations of ARS forms, could be seen as an Egyptian 'import replacement' of African imported tableware.

\section{Conclusion}

This short survey of the concept of 'import substitution/replacement' applied to African tableware production and the transportation of foodstuffs in the inland regions of Africa demonstrates a higher degree of compartmentalisation and complexity in continental rather than Mediterranean areas.

We do not know how far the inland regions of Africa were integrated into Mediterranean trade networks through their possible exports (textiles, oil, wine?), but the imports are equally difficult to identify, except according to the text of different fiscal inscriptions (Zaraï, Lambaesis). The reason is that the development of agricultural production during the second century and the probable high level of transport costs from the coastal

${ }_{91}$ Ballet et al. 2012, 116, n. 232, 233, 238. ${ }_{92}^{92}$ Ballet et al. 2012, 166-17.

${ }_{93}$ Trousset 2003, 366. ${ }^{94}$ About Awjila, see Rebuffat 1970, note 26. 
regions made the pursuit of tableware and (mainly) wine imports progressively pointless. This phenomenon, which reflects the economic situation across the entire province of Africa in the second century, is reflected in the inland regions by the disappearance of transport amphorae and the production of tableware 'import replacements'. The evolution, which was probably ongoing from the late first century $\mathrm{AD}$, is completed at the beginning of the third century, and continued until at least the fifth century.

Differentiations between the social status of settlers and settlements do not allow the model of development through 'import replacement' to be entirely homogeneous. At the same time that the peasants of the Belezma Mountains continue to eat in handmade pottery, ${ }^{95}$ Lambaesis officers drink Ephesian, Sicilian and Campanian wines imported in their original containers. The 'import replacement' pattern is much more widely attested in permanently-constructed farms and in medium-sized towns.

Saharan areas, like Fazzan, seem to closely interact with the pre-Saharan regions, with the same rhythms of 'massive' imports from distant sources (until the end of the second century), and a more autarchic consumption or invisible direct connection with the Mediterranean regions from the third century onwards. Finally, the east-west axis of trade, along the limes 'bypass road', is more in tune with the Mediterranean market. In this case, the merchants were perhaps requested to satisfy a completely different demand, for more sophisticated customers (Roman officers) or more distant destinations (Egypt). ${ }^{96}$

\section{References}

Amraoui, T. 2013. L'artisanat dans les cités antiques de l'Algérie. Unpublished PhD thesis., Université Lumière-Lyon 2.

Amraoui, T. and Bonifay, M. (with a contribution from C. Capelli).

Forthcoming. La céramique de la Maison de la Tigresse à Lambèse:

${ }^{95}$ Fentress 2013, 324

${ }^{96}$ I am very grateful to Elisabeth Fentress, Anna Leone, David Mattingly, and Andrew Wilson for their helpful observations. I thank Touatia Amraoui for allowing the publication here of two drawings from our forthcoming publication on the Lambaesis excavation (figs. 126 and 12.8), as well as Youcef Aïbeche and Aïcha Malek, heads of the Lamboesis archaeological mision. gratitude also goes to Cécile Giroire Heritage Curator, and Head of the Depart mission. My Etruscan and Roman antiquities at the Ioure muserm for her kind permisio pictures of ARS plates from the mus

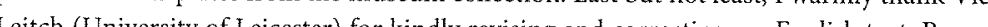
written in 2014 premières observations. In A. Malek (ed.), Les fouilles de la Maison de la Tigresse à Lambèse. Bulletin d'Archéologie Algérienne.

Ballet, P., Bonifay, M. and Marchand, S. 2012. Africa vs Aegyptus: Routes, rythmes et adaptations de la céramique africaine en Égypte. In $S$. Guédon (ed.), Entre Afrique et Égypte; relations et échanges entre les espaces au sud de la Méditerranée à l'époque romaine, Bordeaux: Ausonius (Scripta Antiqua 49), 87-117.

Ben Moussa, M. 2007. La production de sigillées africaines. Recherches d'histoire et d'archéologie en Tunisie septentrionale et centrale, Barcelona: Universitat de Barcelona (Instrumenta 23).

Bonifay, M. 2004. Etudes sur la céramique romaine tardive d'Afrique, Oxford Archaeopress (BAR S1301).

Bonifay, M. 2013. Africa: patterns of consumption in coastal regions vs. inland regions. The ceramic evidence (300-700 AD). In L. Lavan (ed.), Local Economies? Production and Exchange of Inland Regions in Late Antiquity Leiden: Brill (Late Antique Archaeology 10), 529-566.

Bonifay, M. and Capelli, C. (with the collaboration of C. Franco, V. Leitch, L Riccardi and P. Berni Millet) 2013. Les Thermes du Levant à Leptis Magna: quatre contextes céramiques des IIIe et IVe siècles, Antiquités africaines 49: $67-150$.

Bonifay, M., Capelli, C., Martin, T., Picon, M. and Vallauri, L. 2003. Le littoral de la Tunisie, étude géoarchéologique et historique (1987-1993): la céramique, Antiquités africaines 38-39: 125-202.

Bonifay, M., Capelli, C. and Brun, C. 2012. Pour une approche intégrée archéologique, pétrographique et géochimique des sigillées africaines. In M. Cavalieri, in collaboration with E. De Waele and L. Meulumans (eds.) Industria apium. L'archéologie: une démarche singulière, des pratiques multi ples. Hommages à Raymond Brulet, Louvain: Université catholique de Louvain, 41-62.

Brun, J.-P. 2003. Les pressoirs à vin d'Afrique et de Maurétanie à l'époque romaine. Africa n.s. 1: 7-30.

Carandini, A. 1983. Pottery and the African economy. In P.D.A. Garnsey, K Hopkins and C.R. Whittaker (eds), Trade in Ancient Economy, London, 45-62.

Dore, J.N. 1996. The UNESCO Libyan Valleys Archaeological Survey pottery. In G. Barker, D. Gilbertson, B. Jones and D.J. Mattingly (eds), Farming the Desert. The UNESCO Libyan Valleys Archaeological Survey, 2. Gazetteer and Pottery, London: UNESCO/Society of Libyan Studies, 318-89.

Dore, J.N., Leone, A. and Hawthorne, J. 2007, The Fazzan project: the pottery type series. In D.J. Mattingly (ed.), The Archaeology of Fazzan, Vol. 2. Site Gazetteer, Pottery and Other Survey Finds, London, 305-431.

Dossey, L. 2010. Peasant and Empire in Christian North Africa. Berkeley-Los Angeles-London.

Felici, F. and Pentiricci, M. 2002. Per una definizione delle dinamiche economiche e commerciali del territorio di Leptis Magna. L'Africa Romana 14: $1875-900$ 
Nasr, M. 2005. La sigillée africaine dans la région de la Byzacène du Sud-Ouest : production et circuits commerciaux. Unpublished PhD thesis, Université de Provence.

Neuru, L. 1987. Red slipped wares of southwestern central Tunisia: new evidence. In Rei Cretariae Romanae Fautorum Acta 25-26, Augst: Rei Cretariae Romanae Fautores, 175-88.

Neuru, L. 1990. Appendix 2: The pottery of the Kasserine Survey. In Hitchner, B. (ed.), The Kasserine Archeological Survey, 1987, Antiquités africaines 26 : 231-60.

Panella, C. 1989. Gli scambi nel Mediterraneo occidentale dal IV al VII secolo, dal punto di visto di alcune merci. In Hommes et richesses dans l'Empire byzantin, I, Paris: Lethielleux, 129-41.

Peacock, D.P.S., Bejaoui, F. and Benlazreg, N. 1990. Roman pottery production in Central Tunisia. Journal of Roman Archaeology 3: 59-84.

Quaresma, J.C. 2010. Une hypothèse d'importation de sigillée d'Henchir esSrira et de Sidi Aïch à Chãos Salgados (Mirobriga?), Portugal? In Rei Cretariae Romanae Fautorum Acta 41, Abingdon: Rei Cretariae Romanae Fautores, 491-96.

Rebuffat, R. 1970. Routes d'Egypte de la Libye intérieure. Studi Magrebini 3: $1-20$.

Rebuffat, R. 1997. Les marques d'amphores de Bu Niem (Notes et Documents XII). Libya Antiqua ns 3; 163-74.

Rebuffat, R., Deneauve, J., Gassend, J.-M. and Hallier, G. 1967. Bu Njem 1967. Libya Antiqua 3/4: 49-137.

Rebuffat, R., Gassend, J.-M., Guéry, R. and Hallier, G. 1970a. Bu Njem 1968. Libya Antiqua 6/7: 9-106

Rebuffat, R., Gassend, J.-M., Lenne, J. and Rival, M. 1970b. Bu Njem 1970. Libya Antiqua 6/7: 107-165.

Schimmer, F. 2012. Amphorae from the Roman fort at Gheriat el-Garbia (Libya). In Rei Cretariae Romanae Fautorum Acta 42, Bonn: Rei Cretariae Romanae Fautores, 319-25.

Stern, E.M. 1968. Note analytique sur des tessons de sigillée claire ramassés à Henchir es Srira et Sidi Aïch. BABesch 43: 146-54.

Trousset, P. 1974. Recherches sur le limes tripolitanus, du chott el-Djerid à la frontière tuniso-libyenne. Paris: CNRS (Etudes d'Antiquités Africaines).

Trousset, P. 2003. Le tarif de Zaraï: essai sur les circuits commerciaux dans la zone présaharienne. Antiquités africaines 38-39: 355-74.

Weber, M. and Schmid, S. 2012. Supplying a desert garrison. Pottery from the Roman fort at Gheriat el-Garbia (Libya). In Rei Cretariae Romanae Fautorum Acta 42, Bonn: Rei Cretariae Romanae Fautores, 327-35.

Wickham, C. 2005. Framing the Early Middle Ages: Europe and the Mediterranean 400-800. Oxford: Oxford University Press.
13

Pottery and Trade in North and Sub-Saharan
Africa during Late Antiquity The Distribution of North African Finewares

ANNA LEONE

\section{Introduction}

Pottery production in North Africa has been central to debates about ancient Saharan trade from at least the pre-Roman to medieval periods. This paper aims to consider pottery circulation in Late Antiquity in North Africa, comparing material from urban and rural areas in parallel (where possible) ${ }^{1}$ in order to verify the relationship between production centres and distribution in both rural and urban contexts. ${ }^{2}$ However, despite the importance of pottery production, especially in relation to commercial activities within the Roman Empire, it is very difficult to identify true distribution patterns over time. Our understanding is biased by a limited knowledge of the pottery produced after the Late Roman period, but also probably by the fact that pottery was not among the most commonly traded goods - especially on Saharan routes beyond the Roman Empire. ${ }^{3}$ Another factor is the poor recording of certain types of pottery, such as coarsewares, and the broad dates for pottery such as amphorae. For this reason, finewares have been chosen to use as a case study here, since they are more commonly recorded and their forms allow for closer dating. It should also be pointed out that though pottery is a useful proxy for trade in other goods, it cannot be taken as a general indicator for trade, as the history of pottery trade saw periods of boom and decline that are not necessarily reflected in other goods and had its own dynamics. ${ }^{4}$ Having said that, it is nevertheless highly probable that pottery trade patterns

The same approach can be found in Bonifay 2013 with the main focus on the type of production. ${ }^{2}$ I would like to thank Michel Bonifay for his useful suggestions and bibliographical information. Thanks also to David Mattingly for supporting further study on the material from Ghirza and Fazzan in July 2014. Claudio Capellli and Victoria Leitch also gave useful insights.

${ }^{3}$ For a discussion on this issue, see Fentress 2011 and Wilson 2012.

${ }^{4}$ Ballet et al. 2012, 87-88 indicates trends in export activities towards the Eastern Mediterranean: it starts from the mid-third century: there is a boom around the second half of the fourth and the beginning of the fifth century, and a drop in the mid-fifth century then intense activity from the sixth century and it continues into the mid-seventh century. 